МАРКЕТИНГОВІ ЗАХОДИ ЩОДО МОДЕРНІЗАЦІЇ ОБСЛУГОВУВАННЯ У БАНКІВСЬКІЙ СИСТЕМІ УКРАЇНИ

\title{
MARKETING MEANS FOR THE MODERNIZATION OF SERVICES IN THE BANKING SYSTEM OF UKRAINE
}

УДК 339.138:336.71

https://doi.org/10.32843/infrastruct36-46

\section{Філіпковська Л.о.}

к.т.н., доцент,

доцент кафедри економіки

та маркетингу

Національний аерокосмічний

університет імені М.Є. Жуковського

«Харківський авіаційний інститут»

Уманська К.C.

студентка

Національний аерокосмічний

університет імені М.Є. Жуковського

«Харківський авіаційний інститут»

\begin{abstract}
У статті розглянуто основні тенденції та проблеми застосування маркетингу в банківській діяльності. Проаналізовано особливості розвитку банківського маркетингу в Україні. Перераховано види діяльності банківських установ та надано рекомендації щодо поліпшення послуг за допомогою маркетингу. Проаналізовано витрати банків України на маркетингові заходи та рекламу. Охарактеризовано основні маркетингові стратегії в банківській ссрері. Доведено, що раціональні засоби для реалізації цих стратегій засновані на використанні маркетингових інструментів під час надання цільового набору банківських послуг. Виявлено та обірунтовано важливість у банківській сфері взаємодії з клієнтами, а саме встановлення контакту i визначення потреб клієнтів. Запропоновано подієвий маркетинг (івент-маркетинг) як спосіб залучення нових клієнтів, прямих продажів банківського продукту та активізації уваги цільової аудиторії. Практика банківського маркетингу - че крок до розвитку банківської системи України.

Ключові слова: банківська установа, банківська послуга, банківський маркетинг, реклама, маркетингова стратегія, взаємодія з клієнтом, цільова аудиторія, подієвий маркетинг.
\end{abstract}

В статье рассмотрены основные тенденчии и проблемы применения маркетинга в банковской деятельности. Проанализированы особенности развития банковского маркетинга в Украчне. Перечислены виды деятельности банковских учреждений и даны рекомендации по улучшению услуг с помощью маркетинга. Проанализировань расходы банков Украины на маркетинговые мероприятия и рекламу. Охарактеризованы основные маркетинговые стратегии в банковской сорере. Доказано, что рациональные средства для реализации этих стратегий основаны на использовании маркетинговых инструментов при предоставлении целевого набора банковских услуг. Выявлена и обоснована важность в банковской соере взаимодействия с клиентами, а именно установление контакта и выявление потребностей клиентов. Предложен событийный маркетинг (ивент-маркетинг) как способ привлечения новых клиентов, прямых продаж банковского продукта и активизации внимания целевой аудитории. Практика банковского маркетинга - это шаг к развитию банковской системы Украины. Ключевые слова: банковское учреждение, банковская услуга, банковский маркетинг, реклама, маркетинговая стратегия, взаимодействие с клиентом, целевая аудитория, событийный маркетинг.

The development of the banking system in Ukraine proceeds in a crisis in the financial market. In this regard, the management of banks needs to review the program of activities and the tools with which the bank seeks to attract and retain its potential customers. New methods proposed by Western experts for organizing the economic relations of the Ukrainian banking market are associated with banking marketing tools. The main trends and problems of the use of marketing in banking are considered. The features of the development of banking marketing in Ukraine are analyzed. The types of activities of banking establishments are listed. In order to study the need for banking services and implement customer acquisition, a widespread use of marketing is proposed. The expenses of banks of Ukraine on marketing activities and advertising are analyzed. The main marketing strategies in the banking sector are described. It has been proved that rational means for implementing these strategies are based on the use of marketing tools in providing a targeted set of banking services. Based on statistical data on the activities of Ukrainian banks, the trends in the choice of banking services in 2019 are determined, namely: the use of card products, promotional conditions, lending and affiliate programs. Marketing recommendations for improving banking services are provided. The importance of interacting with customers in the banking sector has been identified and justified, namely: establishing contact and determining customer needs. Event marketing is proposed as a way to attract new customers, direct sales of a banking product and increase the attention of the target audience. Event marketing techniques are five times more effective than traditional mailing campaigns and standard phone offers. Using a marketing approach to expanding the banking services market is based on the mechanism of formation of banking resources. The introduction of scientific achievements in the organization of banking services provides continuous updating and improvement of banking products, as well as the use of new technologies for the provision of banking services. The practice of banking marketing is a step towards the development of the banking system of Ukraine.

Key words: banking establishment, banking service, banking marketing, advertising, marketing strategy, customer interaction, target audience, event marketing.

Постановка проблеми. Сьогодні в Україні існує понад 80 банківських установ [1]. Цілями їхньої діяльності $€$ залучення клієнтури, розширення сфрери збуту своїх послуг, завоювання банківського ринку та зростання одержуваного прибутку.

Розвиток банківської системи у світі протікає в умовах кризи на фрінансовому ринку і зростаючої конкуренції між комерційними, а також між ними й державними банками. У зв'язку із цим у керівництва банків виникає необхідність перегляду програми здійснення діяльності та інструментів, за допомогою яких банк буде прагнути залучити й утримати своїх потенційних клієнтів.
Пропоновані західними фрахівцями нові методи організації економічних відносин українського банківського ринку пов'язані з інструментами банківського маркетингу.

Аналіз останніх досліджень і публікацій. Особливості банківського маркетингу висвітлено в роботах як зарубіжних, так і вітчизняних сучасних учених. Великий внесок зробили зарубіжні вчені: Р. Едмістер, Е. Дж. Долан, А.М. Тавас, І.О. Спіцин, Я.О. Спіцин, Г.І. Кравцова, Н.К. Василенко.

Слід відзначити дослідження вітчизняних фрахівців [2-5]. М.Ю. Веселовою проаналізовано сучасні тенденції у розвитку комплексу маркетингу 
українського банку з активним використанням Інтернету. С.М. Козьменко, Т.А. Васильєва, С.В. Леонов розглянули питання втілення інновацій у маркетингову діяльність банківської установи.

В.Г. Костогриз, В.А. Шпильова, Н.О. Слободянюк та О.М. Семенівська дослідили основні інструменти банківського маркетингу, особливу увагу зосереджено на сучасних маркетингових комунікаціях, установлено важливість забезпечення банками індивідуального підходу до обслуговування наявних та залучення нових клієнтів.

Проте недостатньо приділено уваги такій характеристиці маркетингової діяльності банківських установ, як зв'язок споживача 3 наданими послугами, що сприятиме підвищенню конкурентоспроможності банків.

Постановка завдання. Цілями статті $€$ розгляд основних тенденцій та проблем застосування маркетингу в банківській діяльності, а також визначення сутності маркетингових заходів щодо модернізації обслуговування у вітчизняній банківській системі.

Зроблені дослідження мають намір довести ідею, що українським банкам потрібно намагатися розвивати й адаптувати сучасні маркетингові інструменти, використовувані банківськими орахівцями за кордоном.

Виклад основного матеріалу дослідження. Сорера банківських послуг має свою специфріку.
За даними Асоціації українських банків [6], у нашій країні діє 82 організації, що пропонують послуги на банківському ринку.

щодо комерційних банків на рис. 1 показано динаміку їх кількості в Україні.

Країни світу з такою ж територію, як Україна, мають більше банків. Однак стійкість банків і гарантії клієнтам залежать не від кількості банків, а від якості їхньої діяльності.

У системі економічних відносин українського та зарубіжного банківських ринків одним зі складників виступає банківський маркетинг. Для підвищення ефективності діяльності банки вдаються до вдосконалення маркетингових інструментів, що сприяє зростанню їх надійності, фрінансової стабільності та конкурентоспроможності.

У загальному розумінні банківська діяльність це використання грошей у різних формах, якостях і проявах: гроші підприємств, гроші комерційних та державних банків, гроші центрального банку, у фрормі готівки або платіжно-розрахункових документів, а також плата за їх отримання.

Ринок банківських послуг уважається специфрічним. Він відрізняється від інших ринків особливостями відносин та роллю державного регулювання.

Банківська послуга спрямована на оптимальне забезпечення потреб клієнтів й отримання прибутку банком. Фактично банківську послугу

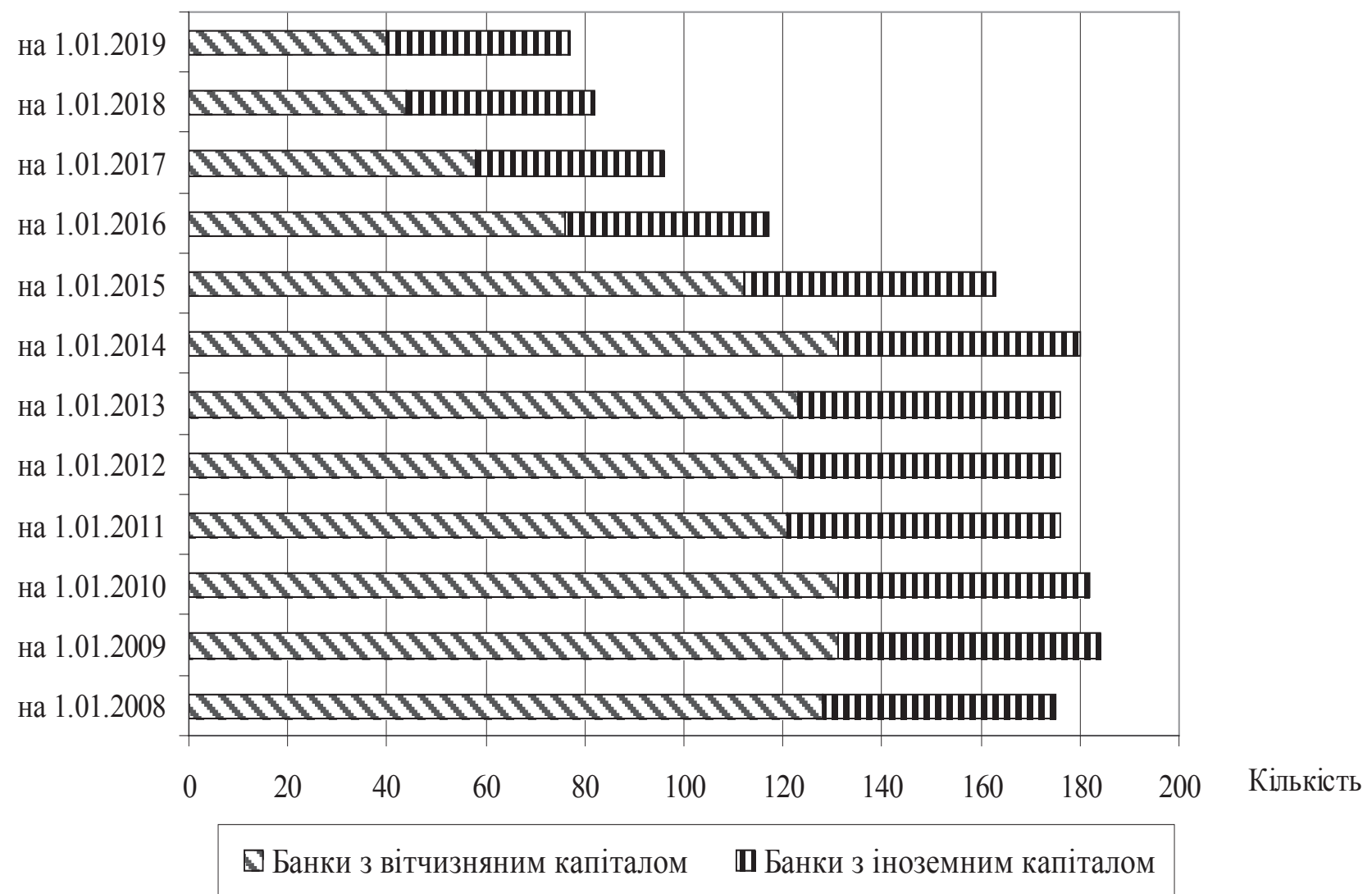

Рис. 1. Динаміка кількості комерційних банків України 
визначають як комплексний результат діяльності банку з максимального задоволення зростаючих із часом вимог клієнта під час проведення банківських операцій або із залучення тимчасово вільних ресурсів [5, с. 28].

Банки пропонують різноманітні послуги. Їх систематизовано та представлено в табл. 1.

Банківські послуги мають специфічні особливості порівняно з продуктами матеріальної сорери виробництва й із загальним поняттям послуги:

- невідчутний характер послуги;

- складність для сприйняття;

- використання грошей у різних фрормах (готівковій та безготівковій);

- довгостроковий характер відносин з банком;

- нерозривність процесу надання й споживання послуги;

- посилення фрактору довіри клієнта, невіддільність послуг від кваліфікації робітників банку;

- прийняття до уваги можливостей парабанківської системи (наприклад, кредитна спілка надає послуги, пов'язані з кредитуванням).

За даними [1] побудовано діаграму, в якій у відсотках показано, якою банківською послугою найчастіше користуються клієнти. Діаграму зображено на рис. 2.

На діаграмі видно, що 78\% опитаних клієнтів користуються послугами банківських установ для оплати комунальних платежів, 61\% клієнтів мають банківські рахунки і пластикові карти. Кредитну заборгованість мають лише 28\% опитаних. Депозитні рахунки відкриті у 11\% населення.
Для вивчення потреби в банківських послугах і залучення клієнтури пропонується широке застосування маркетингу.

Банківський маркетинг призначений удосконалювати та підвищувати ефективність діяльності банку за допомогою набору інструментів у рамках концепції маркетингу з урахуванням ринкової стратегії, заснованої на думці, перевагах і потребах споживачів.

Дослідження інформації [1; 6; 7] дало змогу виявити особливості розвитку банківського маркетингу в Україні, а саме:

1. Специорічність фрінансово-кредитної фрункції банку, висока ціна помилок аналітичних висновків щодо маркетингових прорахунків, різноманітні потреби клієнтів приводять до різного бачення окремих бізнес-напрямів, що не дає змоги ефективно розв'язувати поставлені завдання за допомогою маркетингу.

2. Рівень витрат на комплекс маркетингу розраховується як відсоток від прибутку, а не від доходу.

3. Банківська справа потребує досвіду маркетологів щодо знань з економіки й банківської продукції. Підвищення кваліфрікації банківських маркетологів сприяє виконанню різнобічних завдань.

4. Плинність персоналу впливає на ефективність фрункціонування маркетингових підрозділів банків.

5. В Україні до банківської сорери належать страхові, брокерські, ощадні, трастові й інші компанії, пенсійні фонди, торговельно-промислові і фрінансові корпорації. Банківська діяльність виходить за межі традиційних операцій, посилюється конкуренція з іноземними банками.

Види банківських послуг

Таблиця 1

\begin{tabular}{|c|c|}
\hline Суб'єкти послуг & Види послуг \\
\hline Фізичні особи & $\begin{array}{l}\text { 1. Депозитні вклади. } \\
\text { 2. Кредитування. } \\
\text { 3. Розрахунково-касове обслуговування. } \\
\text { 4. Відкриття та обслуговування рахунків. } \\
\text { 5. Пластикові картки. } \\
\text { 6. Грошові перекази. } \\
\text { 7. Прийом комунальних платежів. } \\
\text { 8. Оренда персональних сейорів. } \\
\text { 9. Дорожні чеки. }\end{array}$ \\
\hline Юридичні особи & $\begin{array}{l}\text { 1. Кредитування. } \\
\text { 2. Депозитні продукти. } \\
\text { 3. Відкриття та обслуговування рахунку. } \\
\text { 4. Схема клієнт-банк. } \\
\text { 5. Пластикові картки (для юридичних осіб видаються карти для виплати заробітної плати). } \\
\text { 6. Інвестиції. } \\
\text { 7. Факторинг (інструмент управління дебіторською заборгованістю для організації). } \\
\text { 8. Міжнародні операції з грошима. } \\
\text { 9. Інкасація. }\end{array}$ \\
\hline Банки & $\begin{array}{l}\text { 1. Міжнародне фрінансування. } \\
\text { 2. Кореспондентські рахунки. } \\
\text { 3. Касові операції. } \\
\text { 4. Надання гарантій. } \\
\text { 5. Випуск облігацій. } \\
\text { 6. Послуги зберігача. } \\
\text { 7. Здійснення переказів. }\end{array}$ \\
\hline
\end{tabular}




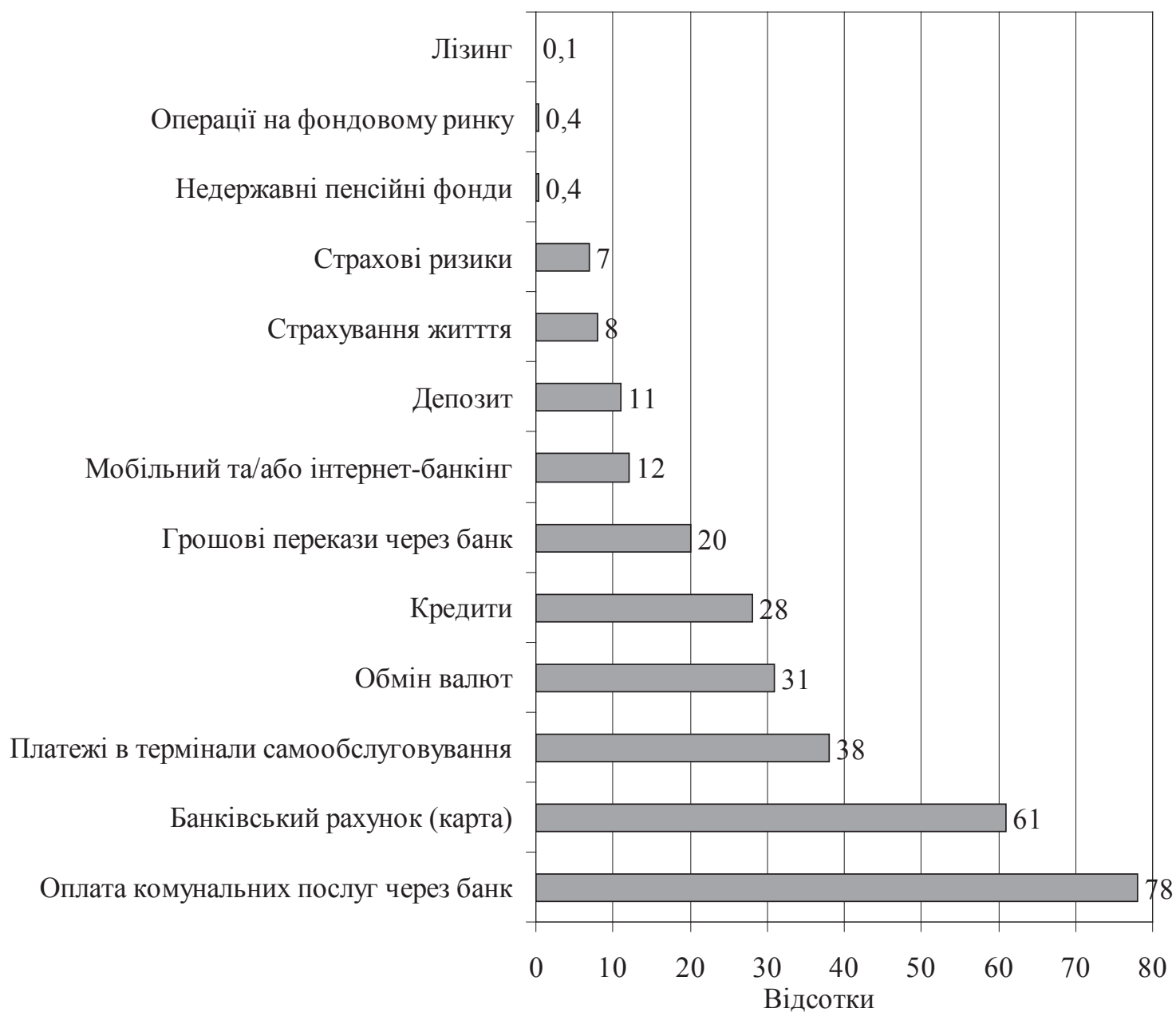

Рис. 2. Рейтинг банківських послуг за популярністю серед населення України

Отже, в Україні перед комплексом банківського маркетингу ставиться завдання пошуку й використання банком найбільш вигідних ринків банківських продуктів з урахуванням реальних потреб клієнтури.

Авторами визначено основні фрункції банківського маркетингу:

- збирання інформації про реалізацію банківських послуг;

- маркетингові дослідження;

- планування діяльності з випуску та реалізації банківських продуктів;

- рекламна діяльність банку;

- сприяння реалізації банківських продуктів.

Особливостями маркетингових досліджень у банківських установах $є$ :

- вивчення поведінки покупця і банків-конкурентів на фрінансовому ринку;

- вивчення банківських продуктів за їх якістю, привабливістю;

- аналіз даних про реалізацію банківських продуктів;

- вивчення конкурентів.

За допомогою маркетингу вирішуються такі завдання:
- встановлення цілей розвитку існуючих банківських послуг;

- створення нових видів банківських послуг;

- дослідження існуючих і виявлення потенційних ринків для надання банківських послуг;

- прогноз потреб клієнтів на банківські продукти;

- вивчення попиту на продукти та послуги банку;

- вироблення банківських послуг, які відповідають потребам клієнтів;

- вибір та встановлення цін на банківські послуги;

- підвищення іміджу банку.

Ураховуючи досвід зарубіжних банків, відповідні установи України планують витрати на власне просування. Так, за січень-квітень 2019 р. банківський сектор витратив на рекламу і маркетинг понад 243 млн. грн [1]. Ця сума на 66\% перевищує результати аналогічного періоду 2018 р. При цьому темп росту бюджету державних банків на просування своїх послуг становив 104\%, такий показник для банків з українським капіталом дорівнює 72\%, банки 3 іноземним капіталом показали найменше зростання рекламних і маркетингових бюджетів (50\%). 
У табл. 2 наведено витрати чотирнадцяти вітчизняних банків на маркетингові заходи на початку 2019 р. та за два минулі роки.

За даними таблиці видно, що банки проранжовано за показником витрат на маркетингові заходи за чотири місяці 2019 р. Перше місце тримає ПУМБ, витрати якого за січень-квітень 2019 р. становили 41,389 млн. грн і зросли на 10,44 млн. грн порівняно 3 аналогічним періодом 2018 р.

Задля модернізації обслуговування у банківській сорері пропонується розглянути маркетингові стратегії, маркетингові можливості підвищення якості банківських послуг та методи спілкування 3 клієнтурою.

Відповідну роль у фрункціонуванні банківських установ грають маркетингові стратегії. Вони $€$ способом виконання поставлених банком завдань та засновані на використанні цільового набору банківських послуг.
Характеристику основних маркетингових стратегій стосовно банківської сфери діяльності представлено в табл. 3.

Відповідно до даних [1; 6] щодо тенденцій вибору банківських послуг у 2019 р., стало фріксування на карткових продуктах, овердрафтах, кеш-беку, акційних умовах, кредитуванні та партнерських програмах. У табл. 4 наведено декілька маркетингових рекомендацій для поліпшення банківських послуг.

Особливу увагу у банківській установі приділяють способам спілкування з клієнтурою [8, с. 22].

Виділяють два етапи взаємодії 3 клієнтами: встановлення контакту і виявлення потреб клієнтів. Спілкування між персоналом банку та клієнтом відбувається за трьома основними каналами: вербальним, звуковим, візуальним. Ці канали мають різну ефрективність щодо дії на клієнта: 10\% становить вербальна дія, що визначається значенням

Таблиця 2

Витрати банків України на маркетингові заходи та рекламу

\begin{tabular}{|c|c|c|c|c|}
\hline Банк & $\begin{array}{c}3 а 4 \text { місяці } \\
2019 \text { р., млн грн }\end{array}$ & $\begin{array}{c}3 a 4 \text { місяці } \\
2018 \text { р., млн грн }\end{array}$ & $\begin{array}{c}\text { Абсолютний приріст: } \\
4 \text { місяці } 2019 \text { р./ } \\
4 \text { місяці } 2018 \text { р., млн грн }\end{array}$ & $\begin{array}{c}\text { Абсолютний } \\
\text { приріст: } 2018 \text { р. I } \\
2017 \text { р., млн грн }\end{array}$ \\
\hline ПУМБ & 41,389 & 30,947 & 10,442 & 65,475 \\
\hline Альфра Банк & 33,580 & 17,391 & 16,189 & 15,495 \\
\hline Універсал Банк & 21,106 & 7,901 & 13,205 & 44,906 \\
\hline Райфрфайзен Банк Аваль & 14,369 & 4,172 & 10,197 & 16,728 \\
\hline Ощадбанк & 13,579 & 6,149 & 7,430 & $-17,944$ \\
\hline ОТП Банк & 12,575 & 5,970 & 6,606 & 9,882 \\
\hline Банк Кредит Дніпро & 11,613 & 2,050 & 9,563 & 10,662 \\
\hline ПриватБанк & 8,631 & 6,592 & 2,039 & 12,911 \\
\hline Прокредит Банк & 8,501 & 2,098 & 6,404 & 9,428 \\
\hline Укрсиббанк & 7,316 & 9,113 & $-1,797$ & 9,676 \\
\hline Аркада & 6,391 & 3,850 & 2,542 & $-8,523$ \\
\hline Ідея Банк & 5,957 & 6,512 & $-0,555$ & 4,503 \\
\hline Укргазбанк & 5,424 & 1,089 & 4,334 & 21,846 \\
\hline Креді Агріколь Банк & 5,285 & 10,518 & $-5,233$ & 13,333 \\
\hline
\end{tabular}

Маркетингові стратегії банківських установ

Таблиця 3

\begin{tabular}{|c|c|c|}
\hline Стратегія & Характеристика стратегії & Заходи щодо реалізації стратегії \\
\hline $\begin{array}{l}\text { Стратегія } \\
\text { розширення } \\
\text { ринку }\end{array}$ & $\begin{array}{c}\text { Передбачає збільшення обсягу } \\
\text { продажів існуючих послуг на } \\
\text { нових ринках }\end{array}$ & $\begin{array}{l}\text { 1. Запровадження нових методів управління відносинами банку } \\
\text { з клієнтами, підвищення довіри клієнта. } \\
\text { 2. Підтримка маркетингових зв'язків із клієнтами. } \\
\text { 3. Використання прямого цінового маркетингу. }\end{array}$ \\
\hline $\begin{array}{l}\text { Стратегія } \\
\text { розвитку } \\
\text { послуги }\end{array}$ & $\begin{array}{l}\text { Пропонує на існуючому ринку } \\
\text { послуги, які мають оновлені } \\
\text { характеристики } 3 \text { метою поліп- } \\
\text { шити їх відповідність ринку }\end{array}$ & $\begin{array}{l}\text { 1. Додавання нових властивостей банківській послузі щодо під- } \\
\text { вищення якості. } \\
\text { 2. Розширення модифрікацій послуг та способів їх надання. } \\
\text { 3. Оптимізація асортиментної політики банку, тобто набору послуг. }\end{array}$ \\
\hline $\begin{array}{l}\text { Стратегія } \\
\text { проникнення } \\
\text { на ринок }\end{array}$ & $\begin{array}{l}\text { Має на увазі розширення сфрери } \\
\text { обслуговування клієнтів або } \\
\text { активне витіснення конкурентів } \\
\text { із вибраного сегмента ринку }\end{array}$ & $\begin{array}{l}\text { 1. Вивчення демограсрічних ризиків. } \\
\text { 2. Залучення клієнтів шляхом підвищення якості всього процесу } \\
\text { надання послуг. } \\
\text { 3. Формування іміджу банку, авторитету серед інших банків та } \\
\text { популярності у клієнтів. }\end{array}$ \\
\hline $\begin{array}{l}\text { Стратегія } \\
\text { диверсифрі- } \\
\text { кації }\end{array}$ & $\begin{array}{c}\text { Передбачає вихід на нові сег- } \\
\text { менти ринку } 3 \text { набором нових } \\
\text { для банку послуг }\end{array}$ & $\begin{array}{l}\text { 1. Розвинення нових напрямів діяльності банківських установ. } \\
\text { 2. Створення бази знань, орієнтованої на клієнта: отримання } \\
\text { довгострокової інорормації про ступінь задоволення від користу- } \\
\text { вання послугами банку або виникнення нових видів потреб. }\end{array}$ \\
\hline
\end{tabular}


Маркетингові рекомендації щодо поліпшення банківських послуг

\begin{tabular}{|c|c|}
\hline Послуга банку & Маркетингова рекомендація \\
\hline $\begin{array}{c}\text { Консультація } \\
\text { з фрінансових } \\
\text { питань }\end{array}$ & $\begin{array}{l}\text { 1. } 3 \text { метою поліпшення надання послуги рекомендовано проводити навчання робітників } \\
\text { в обов'язковому порядку. Для стимулювання персоналу банку призначено штрасри та премії. } \\
\text { 2. Для підвищення якості обслуговування кожному клієнту незалежно від його статусу признача- } \\
\text { ється персональний консультант. Це поліпшить відношення між клієнтами та робітниками банку, } \\
\text { зменшить черги, збільшить довіру клієнта до банку. }\end{array}$ \\
\hline Кредитування & $\begin{array}{l}\text { 1. Впровадження практики управління взаємовідносинами з клієнтами на базі прямої взаємодії, } \\
\text { а також за допомогою СRМ-інструментів. Необхідно організувати базу даних для пошуку потен- } \\
\text { ційних замовників, підтримки інтересу потенційних клієнтів, закриття угод і утримання клієнтів. } \\
\text { Кредитування пропонувати на індивідуальних умовах клієнтам, які мають дійсну потребу. } \\
\text { 2. Організація кредитування на вигідних гнучких умовах. Таким чином, відбувається розуміння та } \\
\text { задоволення бажання клієнта, що є базовою метою банківської установи. }\end{array}$ \\
\hline $\begin{array}{c}\text { Депозитні } \\
\text { вклади }\end{array}$ & $\begin{array}{l}\text { 1. Використання нових каналів продажів, зокрема більш активне залучення такого способу, як } \\
\text { «рекомендації друзів». } \\
\text { 2. Організація мотивування клієнта, з чиєї рекомендації було зроблено вклад у банку, у вигляді } \\
\text { грошового бонусу або додаткового доходу на внесок. }\end{array}$ \\
\hline $\begin{array}{l}\text { Використання } \\
\text { пластикових } \\
\text { карток }\end{array}$ & $\begin{array}{l}\text { Розгляд пропозицій щодо практичного маркетингу пластикових карток (від стратегії до дизайну), } \\
\text { аналізування тенденції майбутнього їх розвитку: } \\
\text { 1. Для різної цільової аудиторії (студенти, пенсіонери) розроблюється свій різноманітний дизайн картки. } \\
\text { 2. Одним із головних чинників під час вибору рахунку є вартість користування карткою (член- } \\
\text { ський внесок). Пропонуються умови, за яких банк не стягує початкового внеску або сума не спи- } \\
\text { сується, якщо рахунок оорормлений у день народження. Також пропонуються акції у свята, щоб } \\
\text { стимулювати залучення нових клієнтів. }\end{array}$ \\
\hline $\begin{array}{c}\text { Інтернет- } \\
\text { банкінг }\end{array}$ & $\begin{array}{l}\text { 1. Розроблення нових прогресивних технологій, завдяки яким мобільні банківські додатки могли } \\
\text { би працювали без підключення до Інтернету. } \\
\text { 2. } 3 \text { метою підвищення зручності клієнта, який користується послугою кредитування й хоче роз- } \\
\text { рахувати суму відсотків, у мобільний додаток додається калькулятор. }\end{array}$ \\
\hline
\end{tabular}

слів, які вимовляє робітник банку; 30\% спричиняється тембром голосу, мелодійністю, ритмом; 60\% відносять до візуального спостережуваними компонентами поведінки (рухами, поглядами, одягом, виразом обличчя, манерою поведінки).

Крім цього, узгодження комунікаційної політики банку, робота 3 послугами й просування банківського продукту проводяться з урахуванням цільової групи. Ці напрями банківського маркетингу стають основою для прийняття управлінських рішень щодо вдосконалення діяльності банку і його комунікаційної політики.

Одним 3 елементів системи інтегрованих маркетингових комунікацій $є$ подієвий маркетинг (івент-маркетинг). Він являє собою складний комплекс із маркетингу, паблік рилейшнз та реклами.

Подієвий маркетинг ґрунтується на маркетинговій концепції, згідно 3 якою необхідною умовою досягнення високого обсягу й якості надання послуг $€$ визначення потреб цільових аудиторій і забезпечення бажаного задоволення інтересів споживачів більш ефективними і продуктивними засобами, ніж конкуренти.

Тому заходи подієвого маркетингу сприяють підвищенню конкурентоспроможності банку, активізації уваги цільової аудиторії, підвищенню обсягу надання конкретних послуг і, головне, забезпеченню організації прямих продажів банківського продукту.

Подієвий маркетинг покликаний фріксувати окремі значущі епізоди життя клієнтів та їхню фрінансову активність. Цей маркетинговий інстру- мент вивчає можливості поліпшення якості та обсягів обслуговування даних клієнтів у зв'язку з тією або іншою подією.

Запропоновано такі заходи подієвого маркетингу у банківській сфрері: виставки, які організовані конкретною установою або кількома банками; презентація банківських послуг; ділові заходи (профресійні конференції, семінари, фроруми та ін.); корпоративні свята; масові заходи, які $є$ способом донесення рекламного, інформаційного повідомлення потенційної клієнтури.

Згідно з даними [1; 7], методи подієвого маркетингу у п'ять разів дієвіші, ніж традиційні кампанії розсилки матеріалів поштою й стандартні телефронні пропозиції.

Висновки з проведеного дослідження. Подальший розвиток банківської сорери України висуває нові завдання перед наукою й практикою маркетингу. Використання маркетингового підходу до розширення ринку банківських послуг базується на механізмі формування банківських ресурсів. Упровадження наукових досягнень в організацію банківського обслуговування забезпечує постійне відновлення та поліпшення банківських продуктів, а також застосовування нових технологій надання банківських послуг.

\section{БІБЛІОГРАФІЧНИЙ СПИСОК:}

1. Офріційний сайт Міністерства фрінансів України. URL : https://minfin.com.ua (дата звернення: 12.09.2019). 
2. Веселова М.Ю. Особенности маркетинга в банковской сфрере. Молодой ученый. 2014. № 18(77). С. 341-345.

3. Козьменко С.М., Васильєва Т.А., Леонов С.В. Маркетинг банківських інновацій. Маркетинг і менеджмент інновацій. 2011. № 1. С. 13-28.

4. Костогриз В.Г. Маркетингові концепції банків $з$ іноземним капіталом. Ефрективна економіка. 2014. № 4. URL : http://www.economy.nayka.com.ua/ ?op=1\&z=2909 (дата звернення: 15.09.2019).

5. Шпильовий В.А. Підходи до класисрікації банківських послуг. Економіка та держава. 2016. № 1. С. 27-30.

6. Офріційний сайт Асоціації українських банків. URL : https://aub.org.ua (дата звернення: 12.09.2019).

7. Ооріційний сайт статистичного вісника НБУ. URL : http://www.bank.gov.ua (дата звернення: 12.09.2019).

8. Лилик І. Ринок маркетингових досліджень в Україні 2015 рік: експертна оцінка та аналіз УАМ. Маркетинг в Україні. 2016. № 1-2. С. 19-33.

\section{REFERENCES:}

1. Ofitsiinyi sait Ministerstva finansiv Ukrainy [The official website of the Finance Ministry of Ukraine]. Available at: https://minfin.com.ua (accessed 12 September 2019).
2. Veselova M.Yu. (2014) Osobennosty marketynha $\mathrm{v}$ bankovskoi sfere [The Features of marketing in banking]. Molodoi uchendi, vol. 18 (77), pp. 341-345.

3. Kozmenko S.M, Vasylieva T.A., Lieonov S.V. (2011) Marketynh bankivskykh innovatsii [Marketing of bank innovations]. Marketynh i menedzhment innovatsii, vol 1, pp. 13-28.

4. Kostohryz V.H. (2014) Marketynhovi kontseptsii bankiv z inozemnym kapitalom [Marketing concepts of banks with foreign funds]. Efektyvna ekonomika [Efficient economy] (electronic journal), vol. 4. Available at: http://www.economy.nayka.com.ua/?op=1\&z=2909 (accessed 15 September 2019).

5. Shpylovyi V.A. (2016) Pidkhody do klasyfikatsii bankivskykh posluh [Approaches to the banking classification services]. Ekonomika ta derzhava, vol 1, pp. 27-30.

6. Ofitsiinyi sait asotsiatsii ukrainskykh bankiv [The official website of the Association of Ukrainian Banks]. Available at: https://aub.org.ua (accessed 12 September 2019).

7. Ofitsiinyi sait statystychnoho visnyka NBU [The official website of the NBU statistical bulletin]. Available at: http://www.bank.gov.ua (accessed 12 September 2019).

8. Lylyk I. (2016) Rynok marketynhovykh doslidzhen v Ukraini 2015 rik: ekspertna otsinka ta analiz UAM [Marketing research market in Ukraine 2015: UAM's expert evaluation and analysis]. Marketynh v Ukraini, vol. 1-2, pp. 19-33.

Filipkovska Larysa

Candidate of Technical Sciences, Associate Professor, Senior Lecturer at Department of Economics and Marketing

National Aerospace University «Kharkiv Aviation Institute»

Umanska Karina Student

National Aerospace University «Kharkiv Aviation Institute»

\section{MARKETING MEANS FOR THE MODERNIZATION OF SERVICES IN THE BANKING SYSTEM OF UKRAINE}

The purpose of the article. In any country, the level of development of the sphere of material production and the economy as a whole largely depends on the level of development of its financial sector. The main structural element of this sector is the banking system.

The increased competition between banks, the emergence and rapid development of non-banking establishments, the outflow of deposits from banks due to the development of the security market, the increase in customer requirements for banking services led to the need to review banking programs and the use of tools by which the bank seeks to attract and retain its potential customers. This is the relevance of the topic.

The purpose of the article is to consider the main trends and problems of the use of marketing in banking, as well as to determine the essence of marketing means for modernizing services in the domestic banking system.

Methodology. The methodological basis of the article is a set of general scientific and special research methods, namely: a comprehensive approach (studying the development trends of the banking sector of Ukraine, as well as the problems of interaction between banks and their customers); system analysis (connection of methods for organizing economic relations of the Ukrainian banking market with banking marketing tools); technological methods (statistical and graphical processing of economic data); monographic method (using event marketing to rationalize the provision of banking services).

Results. The types of activities of banking establishment are listed. The content of the concept of banking services is disclosed. The specific features of banking services are revealed in comparison with the products 
of the material sphere of manufacture and with the general concept of services. The services that customers most often use are identified. In order to study the need for banking services and implement customer acquisition, a widespread use of marketing is proposed.

In Ukraine, finding and using the most profitable banking products markets for the bank, taking into account the real needs of the clientele (customers), are tasks for the banking marketing complex. The authors identified the main functions of banking marketing, namely: collecting information on the implementation of banking services; marketing research; planning activities for the production and sale of banking products; advertising activities of the bank; facilitating the sale of banking products.

To modernize services in the banking sector, it is proposed to consider marketing strategies, marketing opportunities to improve the quality of banking services and methods of communication with the clientele.

The authors paid attention to the main marketing strategies. They are a market expansion strategy, service development strategy, market penetration strategy, diversification strategy. Means for the implementation of strategies are proposed. It has been proved that rational means for implementing these strategies are based on the use of marketing tools in providing a targeted set of banking services.

Based on statistical data on the activities of banks in Ukraine, the trends in the choice of banking services in 2019 are determined, namely: the use of card products, promotional conditions, lending and affiliate programs. Marketing recommendations for improving banking services are provided. The importance of interaction with customers in the banking sector has been identified and justified. They are an establishing contact and determining customer needs. Event marketing is proposed as a way to attract new customers, direct sales of a banking product and enhance the attention of the target audience. Event marketing techniques are more effective than traditional email campaigns and standard phone offers.

Practical implications. The paper studies such a characteristic of the marketing activities of banking establishments as the consumer's connection with the services provided, which will contribute to increasing the competitiveness of banks. Means for the implementation of the bank's marketing strategies are proposed and marketing recommendations for improving banking services are given. Practical means for the application of event marketing are considered. The recommendations provided by the authors can be used by marketers of a banking establishment.

Value/originality. Using a marketing approach to expanding the banking services market is based on the mechanism of formation of banking resources. Implementation of scientific achievements in the organization of banking services ensures continuous updating and improvement of banking products, as well as the use of new technologies for the provision of banking services. The practice of banking marketing is a step towards the development of the banking system of Ukraine. 